\title{
Evaluation of Market Samples of Lauha Bhasma using Namburi Phased Spot Test (NPST)
}

\author{
Research Article
}

\section{Rakshitha D1*, Mandvi Sharma², Gazala Hussain³, Vinay R Kadibagil4}

1,2. PG Scholar, 3. Associate Professor, 4. Professor,

Department of Rasashastra and Bhaishajya Kalpana,

Shri Dharmasthala Manjunatheshwara College of Ayurveda \& Hospital, Hassan.

\begin{abstract}
Introduction: Lauha bhasma is a herbo- metallic preparation in Ayurveda; it possesses ruksha-guru-lekhana guna, madhura vipaka, sheeta veerya which is indicated in kushta, kshaya, pandu, krimi, etc. disease conditions. Though bhasma are prepared by following the classical methods, in this commercialized world its purity and quality is a question. So in this study, classical bhasma pareeksha and Namburi Phased Spot Test (NPST) methods were employed on two market samples of Lauha bhasma to assess their purity and quality. Materials and Methods: Lauha bhasma of both market samples (sample 1 and sample 2) were subjected to classical bhasma pareeksha and NPST test methods. Observations and Results: Both samples were subjected to NPST and different test methods then parameters obtained were compared to standard values as per CCRAS guidelines. Discussion: Both samples of Lauha bhasma have passed the classical bhasma pareeksha suggestive of proper formation ofbhasma but differed in the time period of changes observed at different phases in NPST test. $\mathrm{pH}$ of both samples signifies the alkaline nature of bhasma. Conclusion: Both samples have tested for different parameters in which sample 1 showed changes as mentioned in NPST standards on-time compared to sample 2.
\end{abstract}

Key Words: Bhasma pareeksha, Marana, Bhasma, Sindura, Rekhapurnata, Varitara.

\section{Introduction}

Lauha (Iron) is one among the shuddha dhatu varga (pure metal), chemically identified as Ferrum (Fe) (1). Lauha bhasma possess ruksha (rough)- guru (heavy)- lekhana (scraping) guna, madhura (sweet) vipaka, sheeta (cold) veerya (2). It is netrya (good for eyes), vajikara (aphrodisiac), varnya (complexion), medhya (promotes intellect). Indicated in kshaya (pthisis), kushta (diseases of skin), gulma (abdominal lump), pliha (splenic disease), udaraja krimi (worm infestation in abdomen), pandu (anaemia), prameha (increased frequency and turbidity of urine), arsha (piles), shwasa (asthma), etc. disease conditions (3). In Ayurveda, the process of marana (calcination/ incineration) differs with the nature of the substance to be calcinated. Even though the bhasma (calx) are prepared by following classical methods, in this commercialized world due to the usage of modernized equipments and other issues the quality of a bhasma is always an open question. So many tests can be employed for assessing the quality and purity of a

\section{* Corresponding Author:}

\section{Rakshitha D}

PG Scholar, Department of Rasashastra and

Bhaishajya Kalpana, Sri Dharmasthala

Manjunatheshwara College of Ayurveda \& Hospital,

Hassan- 573201. India

Email Id: rakshuammu2626@gmail.com bhasma preparation in which classical bhasma pareeksha forms the basic parameters mentioned in the classics $(4,5)$.

A new technique was developed and standardized by Dr Namburi Hanumantha Rao in 1970 which was accepted by CCRAS, New Delhi named as Namburi Phased Spot Test (NPST) to assess the purity and quality of prepared bhasma and sindura (mercury preparations) (6). NPST test method helps in identifying the bhasma and also to know whether the bhasma is formed properly or not. Study of the spot at three different time intervals and observation of changes is a special feature of this technique (7). Hence in this study an attempt was made to check the quality assessment on market samples of lauha bhasma using NPST test.

\section{Materials and Methods}

It is divided into two parts

- Subjecting samples to classical bhasma pareeksha

- Conduction of NPST test on both samples

Lauha bhasma of different pharmacies are procured from local market of Hassan, Karnataka and named as sample 1 and sample 2 .

\section{Classical bhasma pareeksha (8)}

Sample 1 and 2 were subjected to various bhasma pareeksha like rekhapurnata, varitara, unama, nirdhuma, etc. 
Rakshitha D et.al., Evaluation of Market Samples of Lauha Bhasma using Namburi Phased Spot Test (NPST)

- Rekhapurnata: This was done by rubbing both samples of bhasma between thumb and index fingers; if it enters the furrows of the fingers then it is considered to be completely done.

- Varitara: Both samples of bhasma are sprinkled over the surface of stagnant water; if the bhasma floats then it is considered to be properly prepared and if it sinks then it is incomplete.

- Unama: A grain of rice or dhanya was placed over varitara bhasma then the grain should float on the surface of bhasma then it is declared to be properly prepared.

- Nirdhuma: Both samples were heated in dry test tubes to observe for any smoke on heating; properly prepared bhasma should not produce any smoke.

- Nischandra: Bhasma of both samples was rubbed between thumb and index fingers and held in bright light; if any shiny particles are present then the bhasma is said to be incomplete.

\section{Evaluation of NPST test (9)}

- Quantity of bhasma- $0.25 \mathrm{~g}$ of each sample

- Reagent- 5N $\mathrm{HNO}_{3}$

- Chemical reacting paper- 10\% Potassium iodide paper

- Initially both samples were weighed and $0.25 \mathrm{~g}$ of each sample was taken in test tubes and heated till bottom appeared red hot using spirit lamp. Then both samples were allowed to cool and treated with $0.5 \mathrm{ml}$ of $5 \mathrm{~N} \mathrm{HNO}_{3}$. Again both samples were heated for a while and shaken often for first two hours before treating with their chemical reacting paper and allowed to settle for 72 hours. After the time duration, one drop from supernatant layer from both samples were placed over $10 \%$ potassium iodide paper and color changes with pattern were observed over three time periods i.e., 0 to 5 minutes- $1^{\text {st }}$ phase, 5 to 20 minutes- $2^{\text {nd }}$ phase and 4 hours after $1^{\text {st }}$ phase- $3^{\text {rd }}$ phase. The changes in the color pattern at different time intervals were compared with the standards given in the NPST book.

\section{Observations and results}

Classical bhasma pareeksha and NPST analysis were carried out on both samples of lauha bhasma given in Table 1 and 2.

Table 1: Classical bhasma pareeksha analysis of both samples of Lauha bhasma

\begin{tabular}{|l|l|l|}
\hline Parameters & Sample 1 & Sample 2 \\
\hline Color & Dark red & Dark red \\
\hline Odor & Absent & Absent \\
\hline Taste & Absent & Absent \\
\hline Touch & Smooth & Fine \\
\hline Rekhapurnata & Positive & Positive \\
\hline Varitara & Positive & Positive \\
\hline Unama & Positive & Positive \\
\hline Nirdhuma & No smoke & No smoke \\
\hline Nishchandrata & No luster & No luster \\
\hline pH & 7.43 & 7.12 \\
\hline
\end{tabular}

Table 2: NPST analysis of both samples of Lauha bhasma (10)

\begin{tabular}{|c|c|c|c|}
\hline \multicolumn{2}{|c|}{ Criteria } & Sample 1 & Sample 2 \\
\hline \multirow[t]{3}{*}{$\begin{array}{l}\text { Changes on } \\
\text { heating }\end{array}$} & $\begin{array}{l}\text { Liberation of } \\
\text { fumes }\end{array}$ & Nil & Nil \\
\hline & Charring & Nil & Nil \\
\hline & Odor & Not specific & Not specific \\
\hline \multirow{3}{*}{$\begin{array}{l}\text { Spot, color } \\
\text { and fading } \\
\text { time at } \\
\text { different } \\
\text { phases }\end{array}$} & $\begin{array}{l}\text { At } 1^{\text {st }} \text { phase } \\
(0-5 \text { minutes })\end{array}$ & $\begin{array}{l}\text { A deep blue } \\
\text { central solid } \\
\text { spot } \\
\text { surrounded by } \\
\text { brown margin } \\
\text { formed } \\
\text { immediately }\end{array}$ & $\begin{array}{l}\text { A deep blue } \\
\text { solid central } \\
\text { spot formed } \\
\text { immediately } \\
\text { with delayed } \\
\text { brown margin }\end{array}$ \\
\hline & $\begin{array}{l}\text { At } 2^{\text {nd }} \text { phase } \\
\text { (5-20 minutes) }\end{array}$ & $\begin{array}{l}\text { A deep blue } \\
\text { central solid } \\
\text { spot } \\
\text { surrounded by } \\
\text { a blue area } \\
\text { with brown } \\
\text { margin } \\
\text { expanded }\end{array}$ & $\begin{array}{l}\text { A deep blue } \\
\text { central solid } \\
\text { spot } \\
\text { surrounded by } \\
\text { a light blue } \\
\text { area with } \\
\text { brown margin }\end{array}$ \\
\hline & $\begin{array}{l}\text { At } 3^{\text {rd }} \text { phase } \\
(4 \text { hours after } \\
\left.1^{\text {st }} \text { phase }\right)\end{array}$ & $\begin{array}{l}\text { A deep blue } \\
\text { central solid } \\
\text { spot } \\
\text { surrounded by } \\
\text { a narrow light } \\
\text { blue area with } \\
\text { only a brown } \\
\text { margin } \\
\text { encircled this }\end{array}$ & $\begin{array}{l}\text { A deep blue } \\
\text { central solid } \\
\text { spot } \\
\text { surrounded by } \\
\text { a light blue } \\
\text { area with } \\
\text { brown margin } \\
\text { formation was } \\
\text { a littledelayed } \\
\text { comparatively }\end{array}$ \\
\hline
\end{tabular}
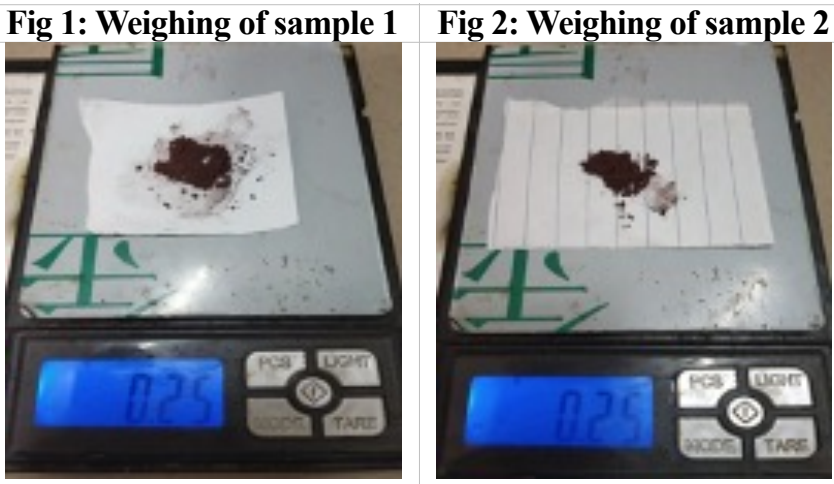

Fig 3: Heating of

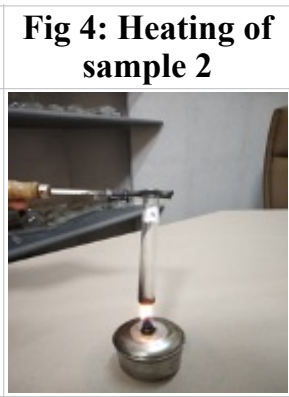

Fig 5: Settling of sample 1

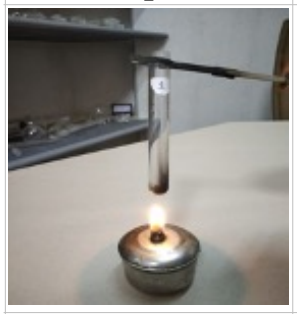
solutions

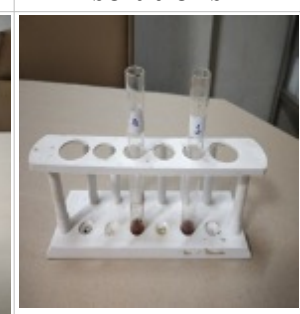


Fig 6 (a to f): NPST evaluation

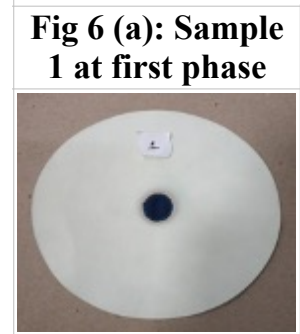

Fig 6 (d): Sample 2 at second phase
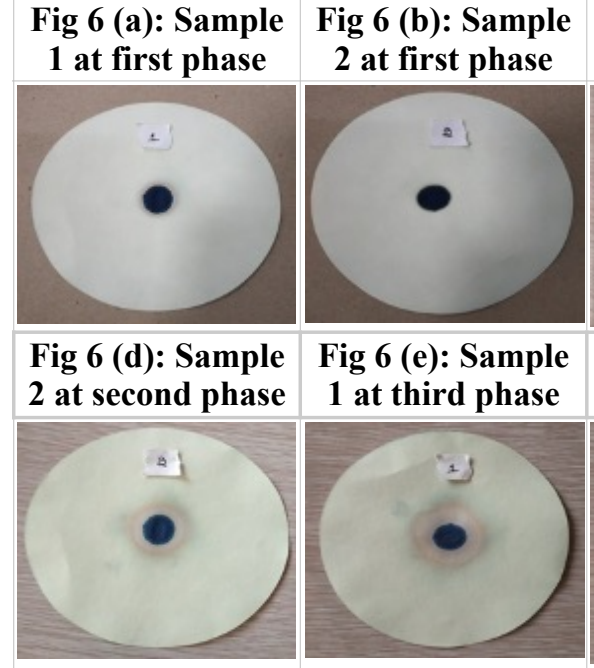

Fig 6 (c): Sample 1 at second phase

\section{Discussion}

Lauha bhasma is one among the herbo- metallic preparation in Ayurveda. Due to the influence of its properties it mainly acts on kshaya, kushta, gulma, pliha, udaraja krimi, pandu, prameha, arsha, shwasa, etc. disease conditions. In this commercialized world, assessing the quality and purity of bhasma before administration is very essential. Though many techniques have been quoted for the quality assessment, in this study classical bhasma pareeksha and NPST are employed over two market samples to check the purity and quality of lauha bhasma.

$\mathrm{pH}$ of both samples suggestive of alkaline nature of the bhasma which may have been influenced by the bhavana dravya used (11). Color of both samples is dark red, odorless with no taste and sample 1 is smooth whereas sample 2 is fine to touch describes the texture of bhasma. Both samples of lauha bhasma have passed the classical bhasma pareeksha suggestive that the bhasma are properly prepared. Rekhapurnata tested entered the furrows of the fingers. Varitara and unama tests showed positive for both samples as the bhasma was unable to break the surface tension of water that made the bhasma to float as it is light (12). Nirdhuma pareeksha produced no smoke on heating of both samples and both were luster free when tested for nischandra test as the bhasma loses its luster when subjected to marana; all these are suggestive of appropriate prepared lauha bhasma (13).

NPST is a unique technique to differentiate between properly processed and unprocessed bhasma and sindura based on chemical reaction which also helps in identification of the bhasma and sindura (14). The test can be conducted with minimum requirements and it is easy to carry out. Observations of both samples were drawn at three different time intervals to assess bhasma quality and purity of market samples. Sample 1 showed exact changes in the pattern of spot that was observed at three intervals of time duration where as sample 2 also showed similar changes but with delayed formation of brown margin at the periphery which is the characteristic feature to identify the quality of lauha bhasma and also sample 2 showed light blue color in surrounding area comparatively. This variation could be because of the chemical changes that occurred in both samples which could be influenced by the duration and number of puta (quantum of heat) given for the preparation of bhasma and also the use of bhavana dravya and influence of modernized equipments used for the preparation by the pharmacies (15).

\section{Conclusion}

In this study, both samples were subjected for bhasma pareeksha explained in treatise of Rasashastra and NPST test methods to assess the purity of quality of market samples of lauha bhasma. Both samples passed all bhasma pareeksha and resulted in the changes as prescribed in standards related to NPST. Sample 1showed exact changes at the right duration as mentioned in the NPST assessment criteria in comparison to Sample 2. The study conducted on both market samples proved the purity and quality of lauha bhasma.

\section{References}

1. Angadi Ravindra. A textbook of Rasashastra. $1^{\text {st }} \mathrm{ed}$. Varanasi; Chaukhamba Surbharati Prakashan; 2014. $354 \mathrm{p}$.

2. Sharma Sadananda. Rasa Tarangini. Edited by KashinathShastri, 11th ed. New Delhi; Motilal Banarasidas publication; 1979. 507p.

3. Sharma Sadananda. Rasa Tarangini. Edited by KashinathShastri, 11th ed. New Delhi; Motilal Banarasidas publication; 1979.508-11p.

4. Simhaguptasunu Vagbhatacharya. Rasa Ratna Samucchaya. Edited by Acharya Yadavji Trikamji with commentary by Ananta Kulkarni Dattatreya. New Delhi; Meharchand Lachhmandas Publications; Reprint 1998.148p.

5. Sharma Sadananda. Rasa Tarangini. Edited by KashinathShastri, 11th ed. New Delhi; Motilal Banarasidas publication; 1979. 22-3p.

6. Bhojashettar S, Poornima B T, Jadar P G. Evaluation of market samples of Yashada bhasma using Namburi Phased Spot Test. Journal of Ayurveda and Integrative Medicine, 2011; 2(2); 69-71. https://www.ncbi.nlm.nih.gov/pmc/articles/ PMC3131774/

7. Rao Hanumanta Namburi. Application of standard Namburi Phased Spot Test in identification of bhasma and sindura preparations of Ayurveda. CCRAS, Dept. of AYUSH, Ministry of Health and Family Welfare. New Delhi; 2010; 6p.

8. Reshma Saokar, et al. Significance of Shastrokta bhasma pareeksha in present era. IAMJ.2016; 4(5); 1-8. http://www.iamj.in/posts/2016/images/upload/ 798_804_1.pdf

9. Rao Hanumanta Namburi. Application of Standard Namburi Phased Spot Test in identification of bhasma and sindura preparations of Ayurveda. CCRAS, Dept. of AYUSH, Ministry of Health and Family Welfare. New Delhi; 2010; 68-71p.

10. Rao Hanumanta Namburi. Application of Standard Namburi Phased Spot Test in identification of 
bhasma and sindura preparations of Ayurveda. CCRAS, Dept. of AYUSH, Ministry of Health and Family Welfare. New Delhi; 2010; 55p.

11. Mitra Shuchi, Prajapati P. K, Shukla V. J and Ravishankar B. Impact of bhavana samskara on physico- chemical parameters with special reference to Gandhaka Rasayana prepared by different media and methods. Ayu. July- Sep 2010; 31(3); 382-86. https://www.ncbi.nlm.nih.gov/pmc/ articles/PMC3221076/

12. Bhange PV, Bhatambre YS. A conceptual review of bhasma pariksha with a modern view. International Journal of Applied Ayurved Research. Jan- feb 2017; 2(11); 4. https://www.ijaar.in/posts/images/ upload/IJAAR_VOL_II_IS S UE_ 11 $1567 \_$1574.pdf
13. Bhange PV, Bhatambre YS. A conceptual review of bhasma pariksha with a modern view. International Journal of Applied Ayurved Research. Jan- feb 2017; 2(11); 5. https://www.ijaar.in/posts/images/ u p 1 o a d / I J A A R_V O L_I I_I S S UE_ 11 _ $1567 \quad 1574 . p d f$

14. Rao Hanumanta Namburi. Application of Standard Namburi Phased Spot Test in identification of bhasma and sindura preparations of Ayurveda. CCRAS, Dept. of AYUSH, Ministry of Health and Family Welfare. New Delhi; 2010.

15. Bhatt Amit, Bajaj Nisha, Kashyap C. P. Effect of number of puta on particle size of vanga bhasma. IAMJ. July 2017; 5(7); 1-6. http://www.iamj.in/ posts/2017/images/upload/2372_2377.pdf. 